\title{
EFFECTS OF INFUSIONS OF SERUM ALBUMIN ON SERUM LIPIDS AND LIPOPROTEINS IN NEPHROSIS
}

\author{
By JAMES H. BAXTER, HOWARD C. GOODMAN AND JAMES C. ALLEN \\ (From the Laboratory of Cellular Physiology and Metabolism, National Heart Institute, \\ Bethesda, Md.)
}

(Submitted for publication July 14, 1960 ; accepted November 3, 1960)

Serum lipid and lipoprotein alterations in nephrosis were discussed in detail in a previous report (1). It was found that there were qualitative as well as quantitative differences in lipoproteins from one patient to another. Despite the differences in lipoprotein pattern, concentrations of serum cholesterol and phospholipids were related inversely to concentrations of serum albumin in a fairly regular manner. Triglycerides were consistently increased only when serum albumin fell below levels of about $1 \mathrm{~g}$ per $100 \mathrm{ml}$. These and other (2) observations suggest that hyperlipoproteinemia in nephrosis may be at least in part a result of hypoalbuminemia.

In order to study the effects on serum lipoproteins of altering the level of serum albumin without altering the disease, repeated infusions of serum albumin were administered to patients with nephrosis. Serum lipids and lipoproteins decreased as a result of the infusions. The decreases often were selective, involving principally the particular fractions which were most excessive at the beginning of the infusions. Changes in lipids and lipoproteins during infusions of dextran, and during steroid-induced remissions of the disease, were studied in several patients for comparison with the albumin results.

\section{METHODS}

Patients. The subjects were 9 patients with nephrosis (nephrotic syndrome) of unknown etiology. Age of the patients ranged from 5 to 46 years. Edema was present in all but one patient and proteinuria (4 to $15 \mathrm{~g}$ per day) was present in all cases prior to the initial course of infusions. A majority of the subjects was hospitalized, fed a low sodium diet, and studied for periods of several weeks before infusions were started. Body weight and levels of serum albumin, serum lipids, and urine protein were reasonably steady, except in $\mathrm{Pa}$ tient R.B., in whom steroid therapy had recently been discontinued, and in one additional patient who was excluded as noted later. Diet, schedule of activities, and other conditions were continued without change through- out the experimental periods. Quantity of food consumed was not rigidly controlled but did not change appreciably.

Albumin infusions. The courses of albumin with one exception consisted of a total of 175 to $1,075 \mathrm{~g}$, given over periods of 7 to 26 days, in quantities of 25 or $50 \mathrm{~g}$ per day with a few exceptions which are noted. The albumin preparation was salt-poor Cohn fraction $\mathrm{V}$ in 25 per cent solution, supplied by the American National Red Cross. Each infusion was administered intravenously over a period of 1 to 2 hours, starting about 7:30 a.m., after first obtaining blood specimens for analysis if desired. Because of the rapid loss of albumin in the case of W.T., a final infusion of $90 \mathrm{~g}$ was given slowly over a 10 hour period.

Dextran infusions. One patient (F.G.) who had previously received albumin, was given 3 daily infusions of dextran in isotonic sodium chloride solution, and another patient (F.N.), a 30 year old male, was given 4 daily infusions of dextran in water. A third patient who received dextran, with results resembling those in F.G., was excluded because of a rapid increase in lipids just before the infusions were started. Each infusion, consisting of $30 \mathrm{~g}$ of dextran (average mole weight 75,000) in 6 per cent solution, was administered intravenously over a period of 6 to 8 hours.

Blood specimens and analytic procedures. Blood specimens for analysis were obtained about 7:30 a.m., after an overnight fast. Specimens during and at the end of the infusion periods were thereby taken almost 24 hours after the end of the most recent infusion. Shorter periods of time elapsed after the long albumin infusion in W.T. and the dextran infusions. Urine was collected continuously in 24-hour pools, starting at 7 a.m. For urine protein determinations, the infusion period was considered to extend to 7 a.m. of the day following the final infusion.

Many of the methods have been described in detail previously (1). Total lipids were determined on chloroform-methanol extracts of serum by the method of Bragdon (3). Determinations of total and free cholesterol were made by the Schoenheimer-Sperry procedure (4). Lipid phosphorus was determined by the method of Stewart and Hendry (5) and multiplied by a factor of 25 to obtain values for phospholipids. Triglycerides were calculated by difference (3), and therefore are possibly less accurate than the other lipids, particularly when triglycerides were relatively low. A modification of the dye interaction method of Rutstein, 
TABLE I

Data on albumin infusions and some of their effects *

\begin{tabular}{|c|c|c|c|c|c|c|c|c|c|c|c|c|}
\hline \multirow{2}{*}{$\begin{array}{l}\text { Patient } \\
\text { and } \\
\text { course }\end{array}$} & \multirow[b]{2}{*}{ Age } & \multirow{2}{*}{\multicolumn{2}{|c|}{$\begin{array}{l}\text { Albumin } \\
\text { infusions }\end{array}$}} & \multicolumn{2}{|c|}{$\begin{array}{c}\text { Serum } \\
\text { albumin }\end{array}$} & \multicolumn{2}{|c|}{ Plasma volume } & \multicolumn{3}{|c|}{ Urine protein } & \multicolumn{2}{|c|}{ Body weight } \\
\hline & & & & I & II & I & II $/ \mathrm{I}$ & I & A & B & I & II \\
\hline & $y r s$ & $g$ & days & \multicolumn{2}{|c|}{$\mathrm{g} / 100 \mathrm{ml}$} & \multicolumn{2}{|l|}{$\stackrel{L}{L}$} & $g / d a y$ & \multicolumn{2}{|c|}{$\begin{array}{c}\% \text { infused } \\
\text { protein }\end{array}$} & \multicolumn{2}{|c|}{$\mathrm{kg}$} \\
\hline $\begin{array}{l}\text { M.C., } 1 \\
\text { M.C., } 2 \\
\text { S.J. }\end{array}$ & $\begin{array}{l}14 \\
14 \\
15\end{array}$ & $\begin{array}{l}225 \\
475 \\
175\end{array}$ & $\begin{array}{c}8 \\
26 \ddagger \\
7\end{array}$ & $\begin{array}{l}0.6 \\
1.8 \\
2.7\end{array}$ & $\begin{array}{l}2.4 \\
4.0 \\
3.5\end{array}$ & $\begin{array}{l}1.96 \\
2.00 \\
2.47\end{array}$ & $\begin{array}{l}0.85 \\
0.86 \\
0.91\end{array}$ & $\begin{array}{r}13 \\
6.5 \\
4.2\end{array}$ & $\begin{array}{r}29 \\
7 \\
29\end{array}$ & $\begin{array}{r}0 \\
0 \\
18\end{array}$ & $\begin{array}{l}46 \\
40 \\
49.5\end{array}$ & $\begin{array}{l}39 \dagger \\
40 \dagger \\
49 \dagger\end{array}$ \\
\hline \multicolumn{13}{|c|}{ Group 2} \\
\hline $\begin{array}{l}\text { R.B., } 1 \\
\text { R.B., } 2 \\
\text { W.T. }\end{array}$ & $\begin{array}{l}6 \\
6\end{array}$ & $\begin{array}{l}100 \\
175 \\
290\end{array}$ & $\begin{array}{l}3 \\
7 \\
8\end{array}$ & $\begin{array}{l}1.0 \\
0.8 \\
0.5\end{array}$ & $\begin{array}{l}1.9 \\
2.8 \\
1.4\end{array}$ & 1.09 & $\begin{array}{l}0.70 \\
0.90 \\
0.93\end{array}$ & $\begin{array}{r}10 \\
6 \\
5.5\end{array}$ & $\begin{array}{l}53 \\
62\end{array}$ & $\begin{array}{r}23 \\
9\end{array}$ & $\begin{array}{l}27.5 \\
23.5 \\
39.5\end{array}$ & $\begin{array}{l}24.5 \\
19 \dagger \\
38.3\end{array}$ \\
\hline \multicolumn{13}{|c|}{ B } \\
\hline $\begin{array}{l}\text { F.G. } \\
\text { C.T. } \\
\text { J.S., } 1 \\
\text { J.S., } 2\end{array}$ & $\begin{array}{r}46 \\
30 \\
5 \\
5\end{array}$ & $\begin{array}{r}650 \\
1,075 \\
325 \\
600\end{array}$ & $\begin{array}{l}13 \\
22 \\
14 \ddagger \\
16 t\end{array}$ & $\begin{array}{l}1.0 \\
0.8 \\
0.6 \\
0.6\end{array}$ & $\begin{array}{l}2.9 \\
3.7 \\
1.4 \\
2.2\end{array}$ & $\begin{array}{l}2.94 \\
2.53 \\
0.85 \\
1.01\end{array}$ & $\begin{array}{l}0.91 \\
0.70 \\
0.86 \\
0.81\end{array}$ & $\begin{array}{c}15 \\
13 \\
8.4 \\
10\end{array}$ & $\begin{array}{l}66 \\
57 \\
56 \\
69\end{array}$ & $\begin{array}{r}15 \\
8 \\
9 \\
11\end{array}$ & $\begin{array}{l}68.5 \\
65.5 \\
25.5 \\
25.5\end{array}$ & $\begin{array}{l}66.2 \dagger \\
57 \dagger \\
24.5 \\
21.5 \dagger\end{array}$ \\
\hline
\end{tabular}

* I = level during control period. II = level at end of infusion period (almost 24 hours after last infusion). A = cumulative excess above control level during infusion period. $\mathrm{B}=$ cumulative excess above control level during postinfusion period.

$\dagger$ Patients were approximately free of edema when these weights were recorded.

$\ddagger$ Infusions were omitted on certain days (see Figures 1 and 4 ).

Ingenito and Reynolds (6) was employed for serum albumin analysis, and urine protein was determined by a biuret method (7). Lipoprotein fractions of serum were isolated by preparative ultracentrifugation after successive adjustments of serum density (1), and analyzed by the methods described above. Free fatty acids were determined by the method of Gordon and Cherkes (8). Determinations of serum dextran were made as described by Semple (9). Changes in plasma volume were calculated from hematocrit readings, $\Delta \mathrm{PV}=\left[\left(\mathrm{Ht}_{1} / \mathrm{Ht}_{2}\right)-1\right] /$ $\left[1-\left(\mathrm{Ht}_{1} / 100\right)\right]$, and from dye $\mathrm{T}-1824$ dilution (10). Optical density read at $660 \mathrm{~m} \mu$ in a Coleman Jr. spectrophotometer was taken as a measure of serum lactescence.

\section{RESULTS}

\section{Effects of albumin infusions}

Data on the albumin infusions and some of their effects are summarized in Table I. In Group I are courses in patients with clear serum and near normal triglycerides, while in Groups $2 \mathrm{~A}$ and $2 \mathrm{~B}$ are courses in patients with high levels of triglycerides as well as total cholesterol and phospholipids. Results of courses in Group 2A are possibly less significant than the others for reasons noted elsewhere.

Serum albumin concentration gradually increased in all patients but one (W.T.), and finally was increased briefly in this case by a large infusion. Proteinuria increased greatly. The maximal levels of proteinuria sometimes were approximately equal to the daily quantities of albumin infused. However, the excess protein in the urine (above the control level), during the infusion period and in the postinfusion period to the point of returning to the control level, was always less than the total quantity of albumin infused. Serum albumin concentration and proteinuria usually returned approximately to preinfusion levels within about a week after the infusions had been discontinued. An exception was the case of M.C. in whom proteinuria increased early in the infusion periods, but then decreased, and fell below control levels after the completion of each of two courses. It is evident that a partial remission of the disease occurred during the administration of albumin in this patient.

Diuresis accompanied the albumin infusions. The decrease in body weight and the increase in serum albumin usually progressed simultaneously. Complete loss of edema occurred in cases in which serum albumin levels were maintained above approximately $2 \mathrm{~g}$ per $100 \mathrm{ml}$. No adverse effects could be attributed to the albumin. Changes 
in serum electrolytes were in the direction of normal. Serum creatinine did not change appreciably. Hypertension or evidence of cardiac failure was not observed. In some cases, there was a striking increase in energy and feeling of wellbeing. However, the relief of symptoms usually did not last long.

The albumin infusions undoubtedly increased plasma volume and caused at least transitory dilution of serum lipids. Dilution also followed removal of blood for analysis. Plasma dilution due to both processes presumably is reflected in the changes in hematocrit readings which were more consistent and at least as great as changes in $\mathrm{T}-1824$ dilution. Ratios of initial plasma volume to final plasma volume, 24 hours after the last infusion-as indicated by changes in hematocrit or, in the case of J.S., with progressive anemia, by dye T-1824 dilution measurements-are shown in Table I. Reductions in concentration of lipoproteins as a consequence of chronic dilution alone probably would not have persisted very long because of the relatively short turnover time of lipoproteins. This is emphasized by the failure of repeated plasmapheresis to decrease plasma lipids in animals (11). It is likely, therefore, that the effects of plasma volume changes per se on lipid concentrations, particularly in the courses of longer duration, were not great. The data presented are observed values, not adjusted for changes in plasma volume, with a few exceptions which are noted.

\section{Effects of albumin infusions on serum lipids}

Some or all of the serum lipids decreased in all cases during the albumin infusions, as may be seen in Table II. The changes during six of the courses are shown in detail in Figures 1-4.

Total cholesterol (TC) decreased by 31 to 60 per cent during all but one course, with no consistent change in ratio of free to total cholesterol. Phospholipids (PL) also decreased in all cases, but to a lesser degree. Ratios of TC/PL, which initially were high, changed toward normal during the infusions, and then increased again after the infusions had been discontinued. Note the convergence and crossing of TC and PL levels during courses shown in Figures 1-4. TC and PL

TABLE II

Changes in serum lipids during albumin infusions *

\begin{tabular}{|c|c|c|c|c|c|c|c|c|c|c|c|c|c|}
\hline \multirow{2}{*}{$\begin{array}{l}\text { Patient } \\
\text { and } \\
\text { course }\end{array}$} & \multicolumn{2}{|c|}{ TL } & \multicolumn{3}{|c|}{ TC } & \multicolumn{3}{|c|}{ PL } & \multicolumn{3}{|c|}{ TG } & \multicolumn{2}{|c|}{$\mathrm{TC} / \mathrm{PL}$} \\
\hline & I & $\overline{I I / I}$ & I & II & II/I & I & II & II/I & I & II & II $/ \mathrm{I}$ & I & II \\
\hline Approx. & \multicolumn{2}{|c|}{$\mathrm{mg} / 100 \mathrm{ml}$} & \multicolumn{3}{|c|}{$\mathrm{mg} / 100 \mathrm{ml}$} & \multicolumn{3}{|c|}{$\mathrm{mg} / 100 \mathrm{ml}$} & \multicolumn{3}{|c|}{$\mathrm{mg} / 100 \mathrm{ml}$} & & \\
\hline $\begin{array}{l}\text { normal } \\
\text { values } \dagger\end{array}$ & \multicolumn{2}{|c|}{580} & \multicolumn{3}{|c|}{180} & \multicolumn{3}{|c|}{225} & \multicolumn{3}{|c|}{100} & \multicolumn{2}{|c|}{0.80} \\
\hline & & & & & & \multicolumn{3}{|c|}{ Group 1} & & & & & \\
\hline $\begin{array}{l}\text { M.C., } 1 \\
\text { M.C., } 2 \\
\text { S.J. }\end{array}$ & $\begin{array}{r}1,703 \\
986 \\
999\end{array}$ & $\begin{array}{l}0.78 \\
0.66 \\
0.76\end{array}$ & $\begin{array}{l}676 \\
373 \\
373\end{array}$ & $\begin{array}{l}446 \\
204 \\
258\end{array}$ & $\begin{array}{l}0.66 \\
0.55 \\
0.69\end{array}$ & $\begin{array}{l}538 \\
308 \\
325\end{array}$ & $\begin{array}{l}409 \\
210 \\
246\end{array}$ & $\begin{array}{l}0.76 \\
0.68 \\
0.76\end{array}$ & $\begin{array}{l}158 \\
115 \\
107\end{array}$ & $\begin{array}{l}256 \\
137 \\
124\end{array}$ & $\begin{array}{l}1.62 \\
1.19 \\
1.16\end{array}$ & $\begin{array}{l}1.26 \\
1.21 \\
1.15\end{array}$ & $\begin{array}{l}1.09 \\
0.97 \\
1.05\end{array}$ \\
\hline & & & & & & \multicolumn{3}{|c|}{ Group 2} & & & & & \\
\hline $\begin{array}{l}\text { R.B., } 1 \\
\text { R.B., } 2 \\
\text { W.T. }\end{array}$ & $\begin{array}{l}2,985 \\
2,132 \\
3,398\end{array}$ & $\begin{array}{l}0.77 \ddagger \\
0.87 \\
0.86\end{array}$ & $\begin{array}{l}837 \\
702 \\
825\end{array}$ & $\begin{array}{l}570 \ddagger \\
571 \\
517\end{array}$ & $\begin{array}{l}0.68 \ddagger \\
0.81 \\
0.63\end{array}$ & $\begin{array}{l}835 \\
578 \\
568\end{array}$ & $\begin{array}{l}629 \ddagger \\
488 \\
470\end{array}$ & $\begin{array}{l}0.75 \ddagger \\
0.84 \\
0.83\end{array}$ & $\begin{array}{r}900 \\
550 \\
1,615\end{array}$ & $\begin{array}{c}814 \ddagger \\
520 \\
1,695\end{array}$ & $\begin{array}{l}0.90 \ddagger \\
0.95 \\
1.05\end{array}$ & $\begin{array}{l}1.00 \\
1.21 \\
1.45\end{array}$ & $\begin{array}{l}0.91 \\
1.17 \\
1.10\end{array}$ \\
\hline \multicolumn{14}{|c|}{ B } \\
\hline $\begin{array}{l}\text { F.G. } \\
\text { C.T. } \\
\text { J.S., } 1 \\
\text { J.S., } 2\end{array}$ & $\begin{array}{l}2,652 \\
2,231 \\
2,593 \\
2,606\end{array}$ & $\begin{array}{l}0.62 \\
0.48 \\
0.53 \\
0.44\end{array}$ & $\begin{array}{l}659 \\
639 \\
736 \\
611\end{array}$ & $\begin{array}{l}414 \\
257 \\
357 \\
346\end{array}$ & $\begin{array}{l}0.63 \\
0.40 \\
0.49 \\
0.57\end{array}$ & $\begin{array}{l}633 \\
456 \\
553 \\
532\end{array}$ & $\begin{array}{l}436 \\
266 \\
353 \\
335\end{array}$ & $\begin{array}{l}0.69 \\
0.58 \\
0.64 \\
0.63\end{array}$ & $\begin{array}{r}1,058 \\
825 \\
950 \\
1,179\end{array}$ & $\begin{array}{l}618 \\
419 \\
506 \\
305\end{array}$ & $\begin{array}{l}0.58 \\
0.51 \\
0.53 \\
0.26\end{array}$ & $\begin{array}{l}1.04 \\
1.40 \\
1.33 \\
1.15\end{array}$ & $\begin{array}{l}0.95 \\
0.97 \\
1.01 \\
1.03\end{array}$ \\
\hline
\end{tabular}

${ }^{*} \mathrm{TL}=$ total lipids $; \mathrm{TC}=$ total cholesterol $; \mathrm{PL}=$ phospholipids $; \mathrm{TG}=$ triglycerides. $\mathrm{I}=$ level before infusions were started; II = level at end of infusion period (almost 24 hours after last infusion).

$\dagger$ Approximate normal values for young adults, discussed previously (1).

$\ddagger$ Because course R.B., 1 was only 3 days long, the lipid values recorded here for Period II are the observed values corrected for the change in plasma volume $(\times 1.43)$. All other values in the table are observed values. 
reached near normal concentrations in the three instances in which serum albumin rose to levels of at least $3.5 \mathrm{~g}$ per $100 \mathrm{ml}$. On the other hand, the quantitative relationship between serum albumin and serum lipids was not consistent.

The relationship between triglycerides (TG) and other lipids in the period before infusions were started differed considerably in different patients, as noted in an earlier study (1). In two patients with normal TG (M.C. and S.J.) and in two with high TG (R.B. and W.T.), there was little or no decrease in TG during the albumin infusions. The failure of $T G$ to fall in the latter two cases (Group 2A) does not seem to be in ac-

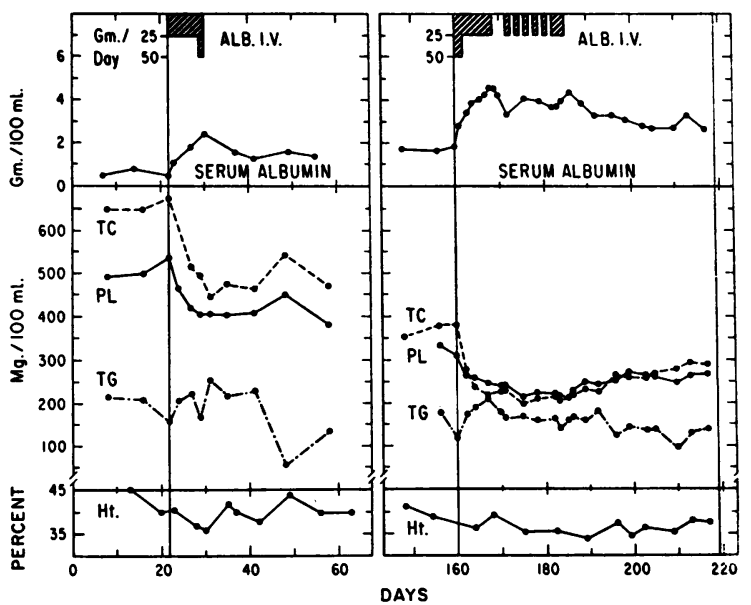

Fig. 1. EfFects of albumin infusions (two courses) on SERUM lipids in Patient M.C.

cord with results in other cases, and may have been due in part to the small quantities of albumin administered, together with effects of recent steroid therapy in R.B., and the very rapid loss of albumin by W.T. In the remaining cases, all with high levels of TG initially, albumin infusions caused large decreases ( 42 to 74 per cent) in TG. Serum lactescence in these cases decreased at least in proportion to the fall in TG. It is evident that the individual lipids were affected differently in different patients by albumin, depending in part upon the pattern of lipids (lipoproteins) present at the beginning of the infusions.

Free fatty acids. Free fatty acids in the serum (FFA) were determined frequently at 7:30 a.m. throughout courses of albumin infusions in three patients (M.C., C.T. and W.T.). Levels of FFA

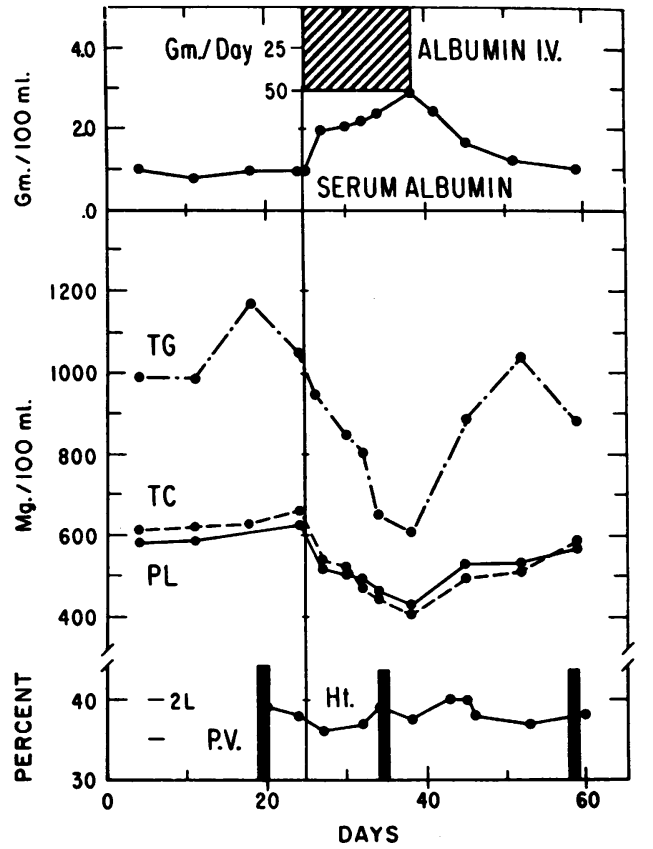

Fig. 2. EfFects of albumin infusions on SeRUm Lipids in Patient F.G.

in these (and other) cases during control periods were normal $(0.25$ to $0.7 \mathrm{mEq}$ per $\mathrm{L})$, in agreement with observations of Shafrir (12). Molar ratios of $\mathrm{FFA} /$ albumin were usually greater than

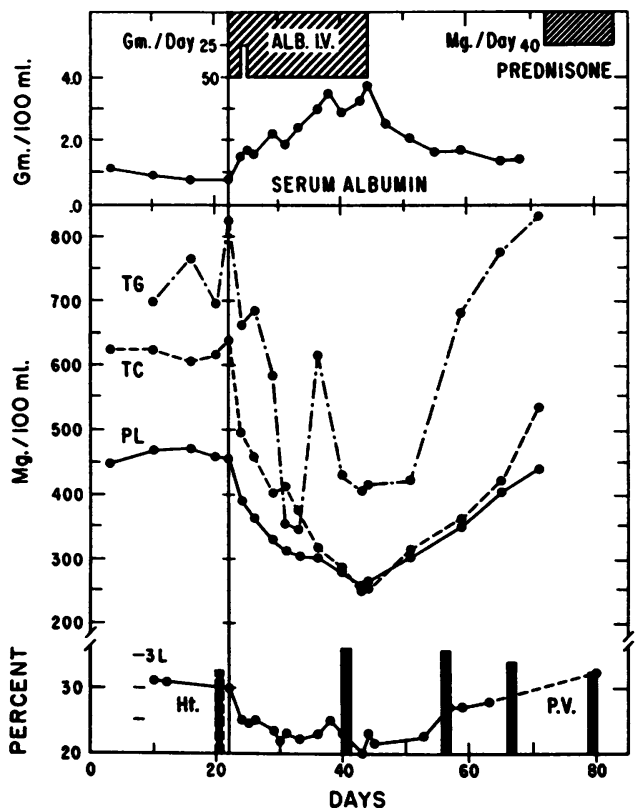

Fig. 3. EFfects of albumin infustons on SERUM LiPIDS in Patient C.T. 


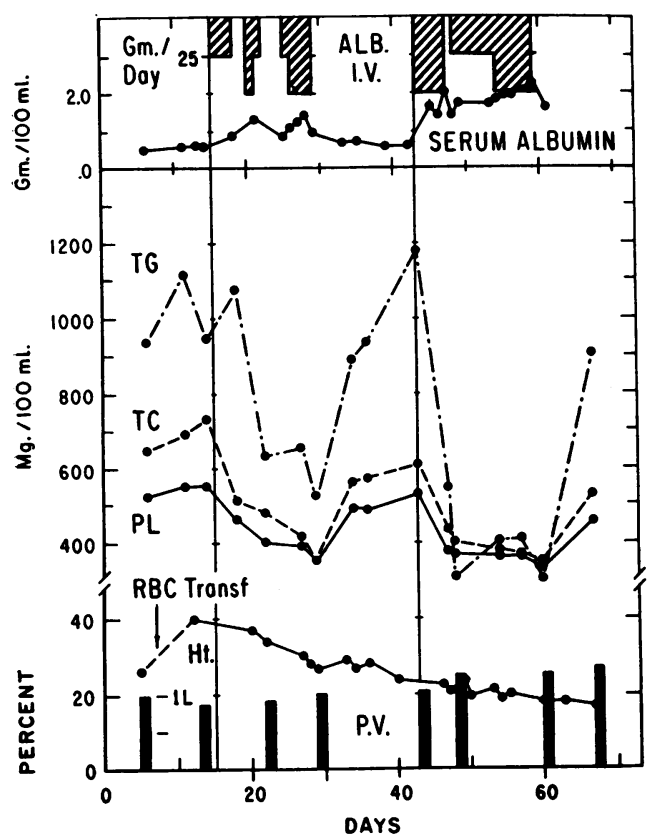

Fig. 4. EFFects of albUMin infusions on SERUM Lipids in Patient J.S.

normal. FFA increased somewhat during the infusions in one case (M.C.) and probably also in another (W.T.), although no concentrations as great as $1.0 \mathrm{mEq}$ per $\mathrm{L}$ were observed. In the patient in whom there was the greatest decrease in lipids (C.T.), no definite change in FFA occurred. In two patients (C.T. and W.T.) FFA did not increase during remissions of the disease induced by prednisone.

\section{Effects of albumin infusions on lipoproteins}

Serum lipoproteins separated by centrifugation (1) were studied during the courses of albumin. In M.C. and S.J., both with normal TG initially, the density (D) 1.019-1.063 lipoprotein fraction decreased to a somewhat greater degree than did the very low density $(D<1.019)$ fraction. This probably also occurred in R.B. and W.T., although the lipoprotein data were inadequate in these cases. In the remaining patients, all with high levels of $\mathrm{D}<1.019$ lipoproteins, the predominant change was a decrease in the $\mathrm{D}<1.019$ fraction. It should be noted that decreases in this fraction involved very significant decreases not only in TG but also in TC, PL and TC/PL. The results are shown in Table III and in Figures 5 and 6. Values for the high density (D 1.063-1.21) lipoproteins probably are much less accurate than the others because of their relatively small size and their liability to error as a result of inaccuracies in separating the other fractions. The lipoprotein changes were in accord with serum lipid changes described above. The addition of albumin to lactescent sera in vitro did not affect lactescence or the distribution of lipids or protein among the lipoprotein fractions of different densities.

\section{Effects of dextran infusions on serum lipids and lipoproteins}

Results of dextran infusions in two patients are summarized in Figures 7 and 8. Because the

TABLE III

Changes in lipids of serum lipoprotein fractions during albumin infusions in three patients with lactescent serum (Group 2B) *

\begin{tabular}{|c|c|c|c|c|c|c|c|c|c|c|c|c|c|c|}
\hline \multirow{3}{*}{$\begin{array}{l}\text { Patient } \\
\text { and } \\
\text { course }\end{array}$} & \multicolumn{6}{|c|}{$\mathrm{D}<1.019$} & \multicolumn{4}{|c|}{ D 1.019-1.063 } & \multicolumn{4}{|c|}{ D $1.063-1.21$} \\
\hline & \multicolumn{2}{|c|}{ TC } & \multicolumn{2}{|c|}{ PL } & \multicolumn{2}{|c|}{ TG } & \multicolumn{2}{|c|}{ TC } & \multicolumn{2}{|c|}{$\mathrm{PL}$} & \multicolumn{2}{|r|}{ TC } & \multicolumn{2}{|r|}{$\mathrm{PL}$} \\
\hline & I & $\overline{I I / I}$ & I & $\overline{I I / I}$ & I & $\mathrm{II} / \mathrm{I}$ & I & $\overline{\mathrm{II} / \mathrm{I}}$ & I & $\overline{\mathrm{II} / \mathrm{I}}$ & I & $\mathrm{II} / \mathrm{I}$ & I & II $/ \mathrm{I}$ \\
\hline & \multicolumn{14}{|c|}{ mg per $100 \mathrm{ml}$ of serum } \\
\hline $\begin{array}{c}\text { Approx. } \\
\text { normal } \\
\text { values* }\end{array}$ & \multicolumn{2}{|c|}{25} & \multicolumn{2}{|c|}{30} & \multicolumn{2}{|c|}{80} & \multicolumn{2}{|c|}{100} & \multicolumn{2}{|c|}{75} & \multicolumn{2}{|r|}{50} & \multicolumn{2}{|c|}{100} \\
\hline $\begin{array}{l}\text { F.G. } \\
\text { C.T. }\end{array}$ & $\begin{array}{l}404 \\
507\end{array}$ & $\begin{array}{l}0.48 \\
0.30\end{array}$ & $\begin{array}{l}379 \\
341\end{array}$ & $\begin{array}{l}0.60 \\
0.41\end{array}$ & $\begin{array}{l}903 \\
799\end{array}$ & $\begin{array}{l}0.57 \\
0.38\end{array}$ & $\begin{array}{l}212 \\
103\end{array}$ & $\begin{array}{l}0.80 \\
0.87\end{array}$ & $\begin{array}{r}190 \\
83\end{array}$ & $\begin{array}{l}0.79 \\
0.77\end{array}$ & $\begin{array}{l}12 \\
24\end{array}$ & $\begin{array}{l}1.00 \\
0.71\end{array}$ & $\begin{array}{l}30 \\
28\end{array}$ & $\begin{array}{l}1.10 \\
0.58 \\
0.88)\end{array}$ \\
\hline J.S., 1 & 412 & 0.29 & 336 & 0.42 & 1,013 & 0.35 & 216 & 0.92 & 164 & 0.92 & 9 & 1.12 & 22 & 1.36 \\
\hline
\end{tabular}

* See footnotes to Table II.

$\dagger$ The results in parentheses were obtained 1 week after albumin had been discontinued, at a time when the lipids of other fractions were only slightly higher than the levels of Period II. 


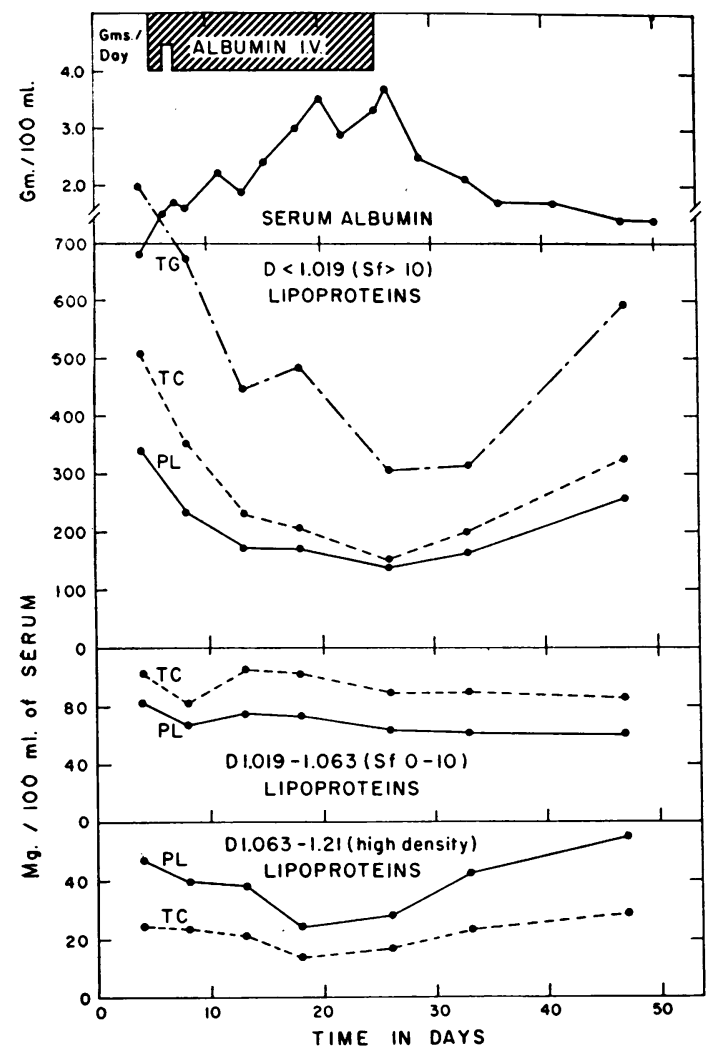

Fig. 5. EFfects of albumin infusions on Lipids in SERUM Lipoprotein fractions of Patient C.T.

courses were brief, concentrations of serum lipids and albumin shown in Figures 7 and 8 after the beginning of infusions have been increased above observed values in proportion to plasma dilution as indicated by changes in hematocrit at each point. Substantial decreases in lipids occurred. In the case of F.N., with near normal TG and clear serum initially, there was little change in TG but definite decreases in TC and PL. In F.G., with high TG and lactescent serum, large decreases in TG as well as in TC and PL resulted. Ratios of TC/PL fell slightly in both instances. The lipid changes persisted after dextran had been largely eliminated from the serum. The lipoprotein changes were in accord with the serum lipid changes and resembled those induced by albumin. In F.N. there was a decrease in the D 1.019-1.063 fraction, while the principal change in F.G. was a fall in the $D<1.019$ fraction. Changes in quantity of the lipoprotein fractions as indicated by PL content are shown in Table IV.

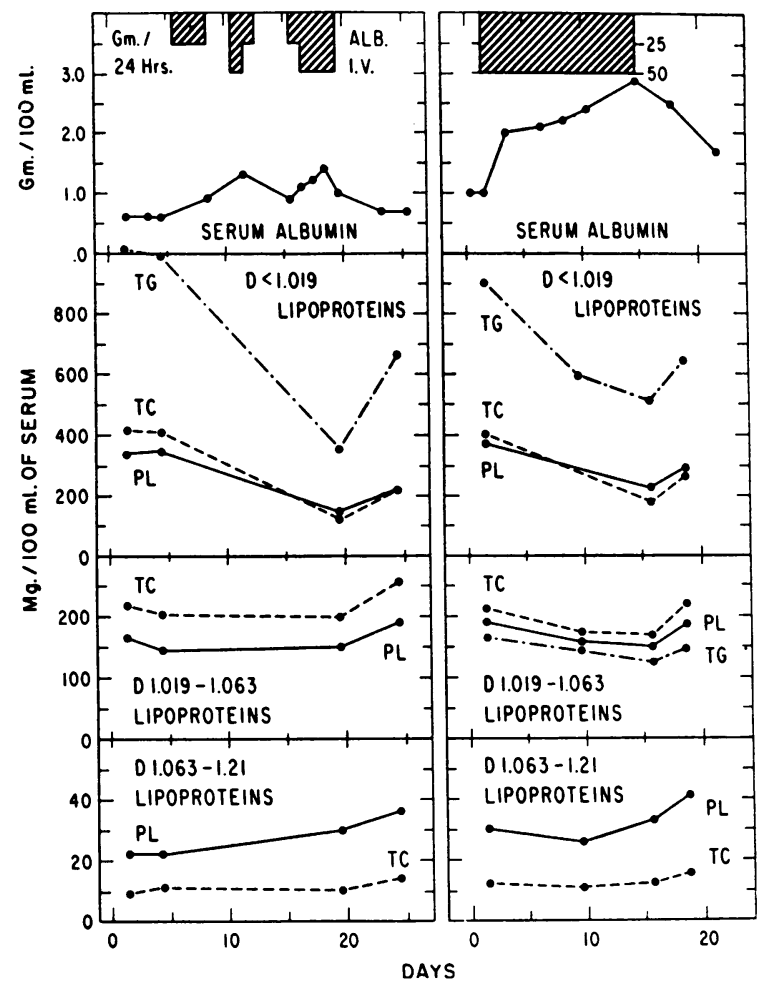

Fig. 6. EFFECTS OF ALbUMin INFUSIONS ON LIPIDS IN SERUM LIPOPROTEIN FRACTIONS OF PATIENT J.S. (LEFT frame) And Patient E.G. (Right frame).

Absence of any appreciable increase in FFA throughout the day of an infusion in the third patient who received dextran (course not shown), and on successive days of infusions in F.N. (Figure 7), suggests that dextran had little if any lipoprotein lipase activity. Dextran caused no complications except for oliguria following the infusions in the third patient. Proteinuria increased significantly during two courses of dextran, in accord with previous observations (13).

TABLE IV

Changes in phospholipid of serum lipoprotein fractions during infusions of dextran *

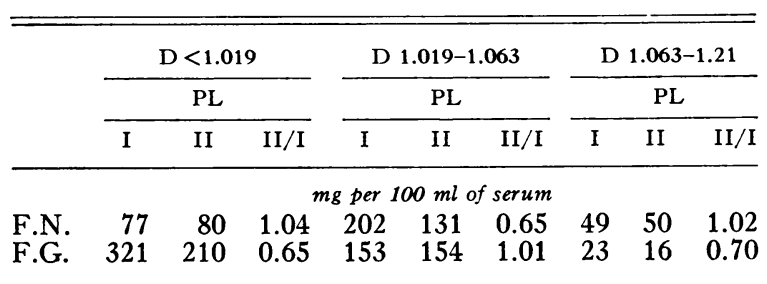

${ }^{*} \mathrm{I}=$ level before dextran infusions. II $=$ level 9 days after dextran infusions. 


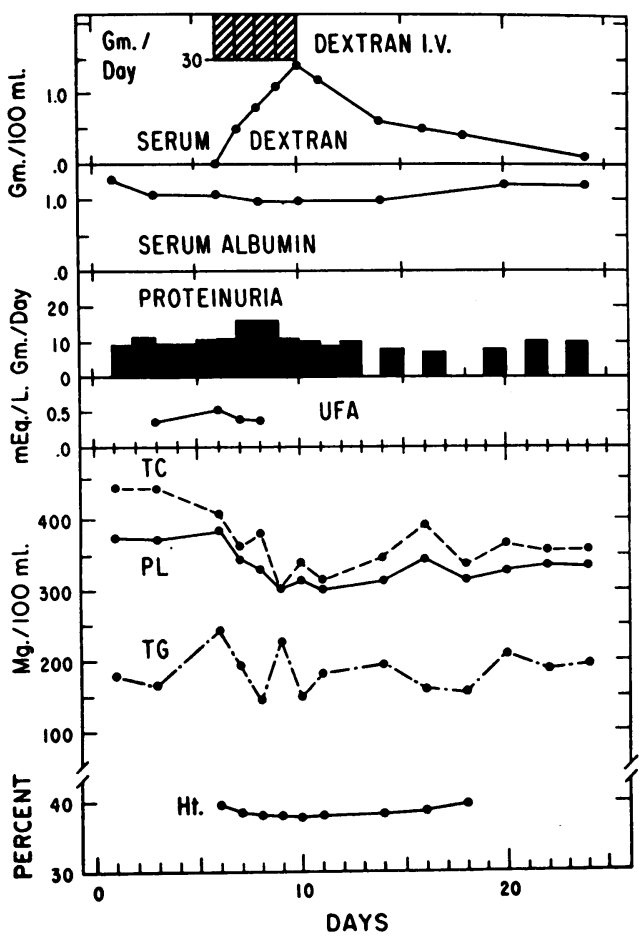

Fig. 7. EFFEcts OF DEXTRAN INFUSIONS ON SERUM Lipids in Patient F.N.

Serum lipids and lipoproteins during changes in the disease

In spontaneous remissions and exacerbations of nephrosis, and in remissions induced by prednisone therapy, serum cholesterol usually changed inversely with serum albumin. Albumin sometimes seemed to change first, but usually the alterations in albumin and cholesterol were very nearly simultaneous. Prednisone usually caused an increase in cholesterol prior to and in the absence of remissions. Changes in PL and TG during steroid therapy have not been studied except as noted below.

Very early in remissions of the disease induced by prednisone in several patients, lipoprotein alterations consisting of a fall in $\mathrm{D}<1.019$ lipoproteins (with a decrease in serum TG and lactescence) together with a rise in the D 1.019-1.063 fraction occurred prior to any great increase in serum albumin concentration. As serum albumin increased, the D 1.019-1.063 fraction fell. The initial lipoprotein changes in these cases possibly were caused by metabolic effects of the steroid and not by changes in the disease, but the ob- servations emphasize the fact that lipoproteins in nephrosis may be greatly influenced by factors other than serum albumin concentration.

\section{DISCUSSION}

Previous observations already referred to suggested that hyperlipoproteinemia in nephrosis might be caused by hypoalbuminemia. On the other hand, serum lipids usually are not increased in portal cirrhosis (14), malnutrition (15), kwashiorkor (16), or the hypercatabolic type of idiopathic hypoalbuminemia (17) in which low levels of serum albumin occur. Possibly this is because of associated nutritional or metabolic disturbances in these diseases when albumin is very low. In the ananabolic type of idiopathic hypoalbuminemia, serum cholesterol is consistently increased and decreases when albumin is infused (17), but the degree and type of lipid alterations and also of edema resemble those seen in nephrosis with higher levels of serum albumin.

In the present study, albumin infusions in patients with nephrosis caused serum lipids and lipoproteins to decrease. Decreases in individual

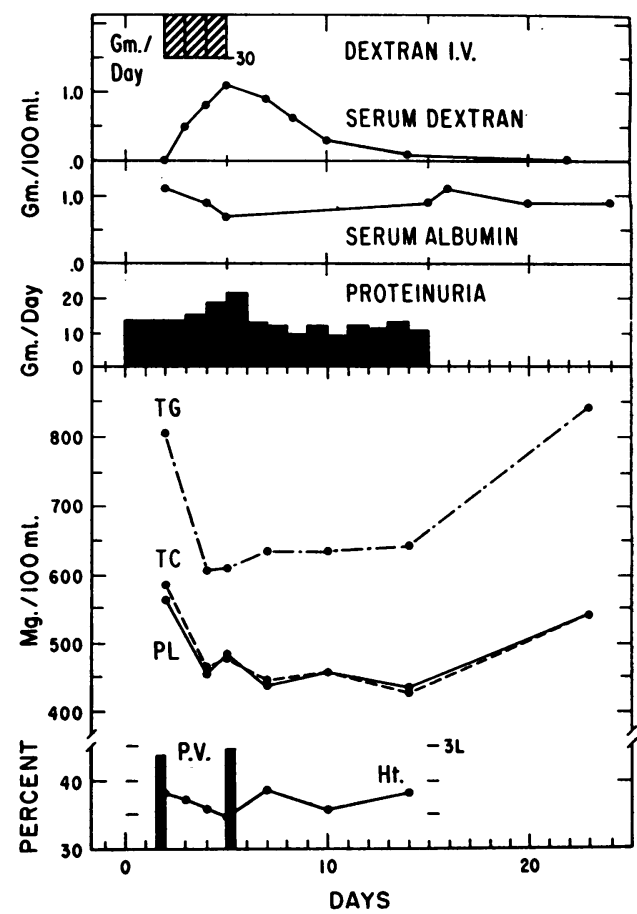

Fig. 8. EFFects of DEXTRAN INFUSIONS ON SERUM LiPIDS IN PATIENT F.G. 
cases did not involve all of the fractions equally. The results could not be explained by simple plasma dilution. However, lipid abnormalities seldom disappeared entirely, and certain ones at times changed little. Further and more consistent corrections might have occurred if satisfactory replacement of albumin had been accomplished more consistently. The magnitude of the effects is difficult to evaluate, but it appeared that lipoprotein metabolism was altered by the albumin infusions. The pathogenesis of nephrotic hyperlipoproteinemia is not necessarily elucidated by the observations, since the reduction in lipids might have resulted from effects of the infusions other than replacement of deficient albumin.

Since free fatty acids are normally bound principally to albumin in the serum (12), the lipid abnormality in nephrosis might conceivably be related to a disturbance in transport or metabolism of FFA due to low serum albumin. Such a mechanism was considered by Gitlin and associates (18) as a possible explanation of their observation that conversion of $\mathrm{S}_{\mathbf{f}} 10-200$ lipoproteins to those of $S_{f} 3-9$ was decreased in nephrotic children. Depression of FFA by 48-hour infusions of glucose, however, failed to cause any great reduction in serum lipids in nephrotic subjects (19).

Peters and Man (20) noted large decreases in serum lipids following albumin infusions in hypoalbuminemic patients with and without nephrosis, whether lipids were originally high or low. There were indications that the changes were not caused by hemodilution. A 50 per cent fall in cholesterol during albumin infusions was observed more recently by Soothill and Kark (21), and was attributed to a decrease in hepatic synthesis of cholesterol occurring in connection with a presumed decrease in albumin synthesis. Allen (22) noted that lipids in nephrotic rats were changed toward normal by injections of various macromolecular substances in addition to albumin. Dextran had previously been observed to decrease serum cholesterol in nephrotic patients (23) and animals (24) and also in normal animals (25). Albumin synthesis appears to be decreased by dextran $(26,27)$. There is no assurance that albumin and dextran act in the same manner. However, the observation that dissimilar substances of large molecular size share the lipid- reducing effect, suggests that the reduction may be mediated through changes in colloidal osmotic pressure or volume of the plasma.

The effects of albumin infusions on serum albumin concentration, proteinuria and edema were similar to those generally noted by previous investigators $(28-32)$.

\section{SUMMARY}

Ten courses of serum albumin, each usually consisting of 25 to $50 \mathrm{~g}$ daily for 1 to 4 weeks, were administered intravenously to seven patients with nephrosis. Serum albumin concentration and proteinuria increased. Complete loss of edema occurred in a majority of instances.

Total serum cholesterol (TC), phospholipids (PL), and ratio of TC/PL, all of which were initially high, fell consistently during the albumin infusions. Serum triglycerides (TG) and lactescence decreased greatly in 3 of 5 patients with initially high levels of TG. In the same three cases there was a selective fall in lipoproteins of density $<1.019$. No decrease in TG occurred in two patients with near normal levels of TG prior to the infusions. Free fatty acids changed inconsistently.

Dextran appeared to induce lipoprotein changes which were similar to those obtained with albumin. Prednisone caused lipoproteins to change prior to any considerable change in serum albumin. The extent and means by which lipids and lipoproteins in nephrosis are altered by albumin, and implications regarding the cause of the lipid abnormality in nephrosis, are discussed.

\section{REFERENCES}

1. Baxter, J. H., Goodman, H. C., and Havel, R. J. Serum lipid and lipoprotein alterations in nephrosis. J. clin. Invest. 1960, 39, 455.

2. Rosenman, R. H., Friedman, M., and Beyers, S. O. The causal role of plasma albumin deficiency in experimental nephrotic hyperlipemia and hypercholesterolemia. J. clin. Invest. 1956, 35, 522.

3. Bragdon, J. H. Colorimetric determination of blood lipides. J. biol. Chem. 1951, 190, 513.

4. Sperry, W. M., and Webb, M. A revision of the Schoenheiner-Sperry method for cholesterol determination. J. biol. Chem. 1950, 187, 97.

5. Stewart, C. P., and Hendry, E. B. The phospholipins of blood. Biochem. J. 1935, 29, 1683.

6. Rutstein, D. D., Ingenito, E. F., and Reynolds, W. E. The determination of albumin in human blood plasma and serum. A method based on the inter- 
action of albumin with an anionic dye-2-(4'hydroxy-benzeneazo) benzoic acid. J. clin. Invest. 1954, 33, 211.

7. Hiller, A., Greif, R. L., and Beckman, W. W. Determination of protein in urine by the biuret method. J. biol. Chem. 1948, 176, 1421.

8. Gordon, R. S., Jr., and Cherkes, A. Unesterified fatty acid in human blood plasma. J. clin. Invest. 1956, 35, 206.

9. Semple, R. E. An accurate method for estimations of low concentrations of dextran in plasma. Canad. J. Biochem. 1957, 35, 383.

10. Chinard, F. P., and Eder, H. A. The determination of the concentration of the dye T-1824 in normal and lipemic plasmas. J. exp. Med. 1948, 87, 473.

11. Sellers, A. L., Hubbard, R., and Marmorston, J. Effects of plasmapheresis on blood cholesterol levels in the dog. Proc. Soc. exp. Biol. (N. Y.) 1957, 95, 67.

12. Shafrir, E. Partition of unesterified fatty acids in normal and nephrotic syndrome serum and its effect on serum electrophoretic pattern. J. clin. Invest. 1958, 37, 1775.

13. James, J., Gordillo, G., and Metcoff, J. Effects of infusion of hyperoncotic dextran in children with the nephrotic syndrome. J. clin. Invest. 1954, 33, 1346.

14. Man, E. B., Kartin, B. L., Durlacher, S. H., and Peters, J. P. The lipids of serum and liver in patients with hepatic diseases. J. clin. Invest. 1945, 24, 623.

15. Man, E. B., and Gildea, E. F. Serum lipids in malnutrition. J. clin. Invest. 1936, 15, 203.

16. Schwartz, R., and Dean, R. F. A. The serum lipids in kwashiorkor. I. Neutral fat, phospholipids and cholesterol. J. trop. Pediat. 1957, 3, 23.

17. Gordon, R. S., Jr., Bartter, F. C., and Waldmann, T. Idiopathic hypoalbuminemias: Clinical staff conference at the National Institutes of Health. Ann. intern. Med. 1959, 51, 553.

18. Gitlin, D., Cornwell, D. G., Nakasato, D., Oncley, J. L., Hughes, W. L., Jr., and Janeway, C. A. Studies on the metabolism of plasma proteins in the nephrotic syndrome. II. The lipoproteins. J. clin. Invest. 1958, 37, 172.

19. Baxter, J. H., Goodman, H. C., and Shafrir, E. Effects of glucose infusions on serum lipids and lipoproteins in nephrosis (abstract). J. clin. Invest. 1959, 38, 986.

20. Peters, J. P., and Man, E. B. The relation of albumin to precipitable iodine of serum. J. clin. Invest. 1948, 27, 397.
21. Soothill, J. A., and Kark, R. M. The effects of infusions of salt-poor human serum albumin on serum cholesterol cholinesterase, and albumin levels in healthy subjects and in patients ill with the nephrotic syndrome. Clin. Res. Proc. 1956, 4, 140.

22. Allen, J. C. Effects of dextran, albumin and polyvinylpyrrolidone on the lipids in experimental nephrosis. Clin. Res. 1959, 7, 278.

23. Mollison, A. W., and Rennie, J. B. Treatment of renal oedema with dextran. Brit. med. J. 1954, $1,893$.

24. Heymann, W., Nash, G., Gilkey, C., and Lewis, M. Studies on the causal role of hypoalbuminemia in experimental nephrotic hyperlipemia. J. clin. Invest. $1958,37,808$.

25. Morrison, A. B. The effect of dextran on serum proteins and serum cholesterol. Quart. J. exp. Physiol. 1956, 41, 51.

26. Carbone, J. V., Uzman, L. L., and Plough, I. C. Changes in serum proteins produced by infusions of dextran. Proc. Soc. exp. Biol. (N. Y.) 1955, 90, 68.

27. Rothschild, M. A., Oratz, M., and Schreiber, S. S. Effect of dextran on the distribution and metabolism of albumin- $\mathrm{I}^{131}$. Clin. Res. 1960, 8, 34.

28. Janeway, C. A., Gibson, S. T., Woodruff, L. M., Heyl, J. T., Bailey, O. T., and Newhouser, L. R. Chemical, clinical, and immunological studies on the products of human plasma fractionation. VII. Concentrated human serum albumin. J. clin. Invest. 1944, 23, 465.

29. Thorn, G. W., Armstrong, S. H., Jr., Davenport, V. D., Woodruff, L. M., and Tyler, F. H. Clinical, chemical, and immunological studies on the products of human plasma fractionation. XXX. The use of salt-poor concentrated human serum albumin solution in the treatment of chronic Bright's disease. J. clin. Invest. 1944, 24, 802.

30. Luetscher, J. A., Jr., Hall, A. D., and Kremer, V. L. Treatment of nephrosis with concentrated human serum albumin. I. Effects on the proteins of body fluids. J. clin. Invest. 1949, 28, 700.

31. Orloff, J., Welt, L. G., and Stowe, L. The effects of concentrated salt-poor albumin on the metabolism and excretion of water and electrolytes in nephrosis and toxemia of pregnancy. J. clin. Invest. 1950, 29, 770 .

32. Eder, H. A., Lauson, H. D., Chinard, F. P., Greif, R. L., Cotzias, G. C., and Van Slyke, D. D. A study of the mechanisms of edema formation in patients with the nephrotic syndrome. J. clin. Invest. 1954, 33, 636. 